\title{
Comparison of Muscle Strength in Stroke Patients between The Given and Not Given Range of Motion Exercise
}

\author{
Eka Rhestifujiayani ${ }^{1}$, Emil Huriani ${ }^{2}$, Muharriza $^{3}$
}

\begin{abstract}
Background: Hemiparesis is a common problem that can caused disability. ROM Exercise is an exercise that to performed evaluate and to improv the function of the musculoskeletal system and is one of therapies in stroke patients that aim to increase cerebral blood flow, minimize disability caused by stroke, so can refine sensory motoric function.

Purpose: The objective of this study was to examine the effect ROM exercises of the extremity muscle strength in patients with stroke

Methods: This study was a quasi experimental with non equivalent control group design. The sampling technique was purposive sampling. The number of sample was 20 respondents. The statistical test used are Wilcoxon test and Mann-Whitney test.

Result: Wilcoxon test in control group showed p-value in upper extremities was $\mathrm{p}=0,157$ and in lower extremities was $\mathrm{p}=0,083$, it mean that there was no increase in muscle strength in the control group and in experiment group showed $\mathrm{p}$-value in upper extremities was $\mathrm{p}=0,004$ and in lower extremities was $\mathrm{p}=0,005$, it mean that there is increase in muscle strength in the experiment group. The result of Mann-Whitney test showed $\mathrm{p}$-value in upper extremities was $\mathrm{p}=0,002$ and in lower extremities was $\mathrm{p}=0,006$, it means that there were differences in the increase in muscle strength between control group and experiment group.

Conclusion: ROM exercises affect the increase in muscle strength in stroke patients with hemiparesis. The ROM exercises can be used as a nursing intervention in the provision of nursing care.
\end{abstract}

Keywords: stroke, range of motion exercises, muscle strength

1,2,3 Faculty of Nursing, Andalas University, Indonesia. Kampus Limau Manis Padang, 25163.

Email:inayaijufitsehr.ake@gmail.com 


\section{BACKGROUND}

Stroke is a common neurologic manifestation and is easily recognized from other neurological diseases because of the sudden onset in a short time (Batticaca, 2012). According to the National Stroke Association (2009), stroke is one of cardiovascular diseases affecting major arteries leading to and located in the brain. Stroke can occur when the supply of blood flow to the brain is blocked or when the blood supply is disrupted due to the rupture of an artery in the brain (Batticaca, 2012). If the incident took place more than 10 seconds will cause permanent damage to the brain (Feigin, 2007).

According to WHO, stroke is one of the three major causes of death in the world among other dangerous diseases such as cancer and heart deseases. In the United States approximately 5 million people have experienced stroke, and neurological deficit due to stoke, and two-thirds of this deficit is severe (Perry \& Potter, 2006).

According to the Regional Health Research Department of Health of the Republic of Indonesia in 2011, the report found that in Indonesia, every 1000 people, 8 of them experienced stroke. Stroke is the leading cause of death at all ages, with a proportion of $15.4 \%$. Every seven people who died in Indonesia, one of them is due to stroke (Depkes RI, 2011, quoted by Sikawin, Mulyadi \& Palandeng, 2013).

Stroke may reveal symptoms, or may not (stroke without symptoms is called silent stroke), depending on the place and the size of the damage and the type of stroke. Symptoms of stroke may be physical, psychological and / or behavioral. Typical symptoms of the stroke are weakness arm and / or leg on one side of the body reaches almost $80 \%$, loss of sensation of the face, speech difficulty or incomprehesion (without hearing problem) and swallowing difficulties. Approximately $90 \%$ of patients who had stroke, experiencing sudden onset of weakness (hemiparesis) or paralysis of half the body (NSA, 2009; Batticaca, 2012).

Main impact of stroke is decrease of hemiplegy physical mobilization, such as hemiplegy and hemiparesis. Other symptoms that may appear is the partial loss of vision, dizziness, double vision, slurred speech, impaired balance and the most severe is permanent paralysis (Batticaca, 2012).

Hemiparesis is muscle weakness on one side of the body, which causes weakness or inability to move one side of the body. Weakness may affect the arms, hands, feet and face muscles. Patients may have difficulty performing daily activities such as eating, dressing, bathing and grabing objects (NSA, 2009). Hemiparese on the arms, hands, face, chest, legs or feet can cause: loss of balance, difficulty on walking, impaired ability to grasp objects, a decrease in precision motion, muscle fatigue, and lack of coordination (NSA, 2009).

With the increase of the incidence of stroke and the disability, if the ROM exercise is not implemented as early as possible there will be a decrease in muscle strength, muscle atrophy, contractures and decubitus wound. In fact, the hospital, such events like is the often the case despite having gained control of hospital health workers (Irfan, 2010). 
ROM exercises is rehabilitative therapy aimed at improving or maintaining the flexibility and muscle strength. Provision of early range of motion exercises can improve muscle strength because it can stimulate the motor unit so that the more the motor units involved, there will be an increase in muscle strength (Irfan, 2010).

In theory, it is not known specifically about the intensity of ROM exercises. According to Perry and Potter (2008), ROM exercises performed 2 times a day, with a minimum of repetition 8 times in every movement. ROM exercises can be done at all joints or only on parts such as the neck, fingers, arms, elbows, shoulders, knee, foot and ankles are suspected of having the disease as one extremity weakness.

Based on the results of research conducted by Mawarti and Farid on the effect of passive ROM exercise to increase muscle strength in patients with stroke (2012), showed that there was a significant effect of passive ROM exercises to increase muscle strength in patients with stroke. This study is also in line with research conducted by Sikawin, Mulyadi and Palandeng, about the effects of ROM exercise on muscle strength in patients with stroke (2013), shows the influence of ROM exercises for muscle strength in patients with stroke.

Implementation of ROM exercises should be tailored to the patient's condition, for patients with stroke due to thrombosis and embolism if no other complications can begin after 2 to 3 days after the attack and in case of bleeding subaracnoid started after 2 weeks, thrombosis or embolism were no myocardial infarction without other complications began after the 3rd week and if there is no arrhythmia starts on day 10th. Implementation is done routinely in practice time between 45 minutes which was divided into three sessions and each session was given a 5-minute break, but when the patient looks tired, there are changes in the face and no prominent increase in vital signs of each exercise, then it must be stopped immediately (Black \& Hawks, 2009).

Muscle strength generally required to perform the activity. All movements generated by a person is the result of an increase in muscle tension as a motor response. Muscle strength can be described as the ability of the muscle to withstand the load either external or internal loads (Irfan, 2010).

Muscle strength can be measured over a range of motion by asking the patient to pull or press custody given by nurses. Nurses can compare both limb muscle strength and should be remembered that the dominant limb will usually show greater strength (Paternostro-Sluga, 2008).

Dr. M. Djamil Padang Hospital is a teaching hospital Class B and referral on Central Sumatra. Preliminary studies conducted by researchers of September 18, 2014, the mobilization of stroke with ROM exercises in neurology unit Dr. M. Djamil Padang hospital referred to medical rehabilitation and physiotherapy done by officers. Refer patients to medical rehabilitation by the doctor if the patient hemodynamics as well as the patient's general condition is good about the third or fourth day of treatment. There are 5 people in hospitalized patients in neurology unit, 4 patients had weakness of one 
side and one patient suffered paralysis of one side, one patient has not been scheduled physiotherapy, 2 patients already scheduled for physiotherapy but has not been implemented and do not know reason why has not been implemented, and 2 patients had been doing physiotherapy in accordance with the scheduled that three times a week, but the patient complained always queue up and wait a long time for physiotherapy due to limited number of physiotherapist, where as that provided only in the morning.

ROM exercises are done in neurology unit is approximately three times a week for a half an hour by physiotherapist, according to researchers had not been optimal to restore muscle strength is weak. The weakening of muscle strength in patients with post-stroke partner takes great care in the rehabilitation process, the early and regular rehabilitation process, the greater the chance the possibility of improving the physiology of the body and the decrease of complications after a stroke.

\section{OBJECTIVE}

The objective of this study was to examine the effect of ROM exercises of the extremity muscle strength in patients with stroke.

\section{METHODS}

Type of research is a quasi experimental study with non equivalent control group (Notoatmojo, 2010; 2012). Subjects in this study were patients who experienced hemiparesis, than was observed for muscle strength before and after the ROM exercises twice a day for seven days.

The sampling technique used was purposive sampling. Respondents in this study were patients with stroke who have passed the critical phase and meet the inclusion criteria of stroke patients who experienced a first attack hemiparesis, patients were treated on day 3 to day 14 after an acute attack of stroke, compos mentis cooperatif (GCS 13-15), aged 20-60 years, not impaired thought processes and functions of both vision and hearing.

The sample in this study were 20 respondents were divided into two groups: control group and experimental groups, each group of 10 respondents. The control group was not given range of motion exercises, while the experimental group was given passive range of motion exercises and active for 7 days twice a day (Perry\&Potter, 2008; 2011; Irfan, 2010).

ROM exercises performed passively and actively, in the upper extremities movement, namely: (1) The movement of the shoulder: flexion, extension, hyperextension, abduction, adduction, rotation, external rotation and sirkumduksi. (2) The movement of the elbow: flexion and extension. (3) The movement of the forearm: supination and pronation. (4) The movement of the wrist and fingers: flexion, extension, hyperextension, abduction and adduction. (5) The movements of the thumb: flexion, extension, abduction, adduction and opposition. And movement of the lower extremities, namely: (1) The movement of the hip: flexion, extension, hyperextension, abduction, adduction, rotation, external rotation and sirkumduksi. (2) The movement of the knee: flexion and extension. (3) The movement of the ankle: dorsiflexion and plantar. (4) The movement of the foot: inversion and eversion. (5) The movement of the 
toes: flexion, extension, abduction, adduction (Irfan, 2010; Potter \& Perry, 2011; Saputra, 2013).

Clinical assessment of muscle strength was assessed by classifying the patient's ability to contract the voluntary muscles against gravity and against resistance examiner. Alternatively, the patient is asked to perform a full extension or flexion against resistance from the examiner. Muscle strength categorized from 0 (no evidence of force) to 5 (complete or full custody), the assessment carried out on the three last joints averaged were the upper extremities are the hands, elbows and shoulders, and the lower extremities are the legs, knees and pelvis. The scale used is the Medical Research Council Scale (MRCS) (Paternostro-Sluga, 2008; Irfan, 2010).

This study used four principles of research ethics by milton (1999) in Notoadmodjo (2012), namely: (1) Respect for human dignity by using informed consent that includes: explanation of the benefits of research, explanation of possible risks and inconvenience caused, the explanation of the benefits, approval of that respondent may resign as the research object at any time, and guarantee anonymity and confidentiality of the identity and the information provided by respondents. (2) Respect the privacy and confidentiality of research subjects by using a coding as the identity of respondents. (3) Fairness and transparency by explaining the research procedures include the selection of the sample, the distribution in the study group using the envelope system is chosen directly by the respondents, so no difference in the chance to be experimental or control group. (4) Calculate the benefits and harm caused by trying to minimize the adverse impact on the respondent to undergo good communication, mutual trust between researchers, respondents and family. The study was conducted in November 2014, at neurology unit Dr. M. Djamil Padang Hospital. Muscle strength in the analysis using the mean, standard deviation, maximum and minimum values. The statistical test used was Wilcoxon test to see the effect of pretest-posttest in both groups (Dahlan, 2012; Sunyoto \& Setiawan, 2013), and the Mann-Whitney test to see the difference in effect between the two groups (Dahlan, 2012).

\section{RESULT}

Characteristics of the respondents in this study is known that more than half of the respondents were female control group as many as 6 people $(60 \%)$. Different conditions found in the experimental group, where more than half of the male sex as many as seven people $(70 \%)$. Based on the known side paralysis that more than half of respondents control and experimental group experienced paralysis of the right side as many as seven people (70\%), and based on the known age in the control group that over half of middle aged adults were 9 people $(90 \%)$ and all respondents in the experimental group of 10 middle aged adults (100\%). 
Table 1. Comparison of mean scores without muscle strength and range of motion exercises in the control and experimental groups in Dr. M. Djamil Padang hospital.

\begin{tabular}{|c|c|c|c|c|c|c|c|c|}
\hline \multirow{3}{*}{$\begin{array}{c}\text { Muscle } \\
\text { Strength }\end{array}$} & \multicolumn{8}{|c|}{ Groups } \\
\hline & \multicolumn{4}{|c|}{ Control $(n=10)$} & \multicolumn{4}{|c|}{ Experiment $(n=10)$} \\
\hline & Min & Max & Mean \pm SD & p-value & Min & Max & Mean \pm SD & $\begin{array}{c}\text { p- } \\
\text { value }\end{array}$ \\
\hline Upper ... & & & & 0,157 & & & & 0,004 \\
\hline - pre & 1 & 3 & $1.70 \pm 0.675$ & & 1 & 3 & $210+0.738$ & \\
\hline - post & 1 & 4 & $1,90 \pm 0,994$ & & 1 & 4 & $3,10 \pm 0,994$ & \\
\hline $\begin{array}{l}\text { Lower } \\
\text { extremities }\end{array}$ & & & & 0,083 & & & & 0,005 \\
\hline - pre & 1 & 2 & $1,70 \pm 0,483$ & & 1 & 3 & $1,90 \pm 0,568$ & \\
\hline - post & 1 & 3 & $2,00 \pm 0,816$ & & 2 & 4 & $3,00 \pm 0,816$ & \\
\hline
\end{tabular}

Based on the results in Table 1 the experimental group, the upper limb in the pretest get that muscle strength highest scores is 3 and the lowest is 1 with average muscle strength was $2.10 \pm 0.738$, while the value of muscle strength in the upper extremities posttest, in get that scores the highest muscle strength is 4 and the lowest is 1 . With average muscle strength was $3.10 \pm 0.994$. Wilcoxon test results showed $p$-value was $0.004(p<0.05)$, which means that there is a significant change to the upper extremity muscle strength after a given range of motion exercises for seven days as much as 2 times a day. And on the lower extremities, the value of muscle strength in the lower extremities pretest, showed the highest muscle strength score is 3 and the lowest is 1 with average muscle strength was $1.90 \pm 0.568$. While the value of muscle strength in the lower extremities posttest, showed the highest scores is 4 and the lowest is 2, with average muscle strength was $3.00 \pm 0.816$. Wilcoxon test results showed p-value was 0.005 ( $p<0.05$ ), which means that there are significant changes in lower limb muscle strength after a given range of motion exercises for seven days as much as 2 times a day.

Based on the results in Table 1 the control group, on the upper extremities pretest, in getting that score the highest muscle strength is 3 and the lowest is 1 , the average muscle strength was $1.70 \pm 0.675$, while the value of the upper extremity muscle strength in the posttest, the get that score the highest muscle strength is 4 and the lowest is 1 , the average muscle strength was $1.90 \pm 0.994$. Wilcoxon test results showed pvalue was $0.157(\mathrm{p}<0.05)$, which means that there are no significant changes to the upper extremity muscle strength without a given range of motion exercises. And on the lower extremities, the value of muscle strength in the lower extremities pretest, showed the highest muscle strength score is 2 and the lowest is 1 , the average muscle strength was $1.70 \pm 0.483$. While the value of muscle strength in the lower extremities posttest, shows the highest score was 3 and the lowest was 1 , the average muscle strength was $2.00 \pm 0.816$. Wilcoxon test results showed $\mathrm{p}$-value was $0.083(\mathrm{p}<0.05)$, which means 
that there are no significant changes in lower limb muscle strength without a given range of motion exercises.

Table 2. Comparison of the mean improvement in muscle strength scores between the control and experimental groups in Dr. M. Djamil Padang hospital

\begin{tabular}{lccccc}
\hline Muscle strength & n & Min & Max & Mean \pm SD & p-value \\
\hline Upper extremities & & & & & 0,002 \\
- Control group & 10 & 0 & 1 & $0,20 \pm 0,442$ & \\
$\quad$ - Experiment group & 10 & 0 & 2 & $1,00 \pm 0,471$ & \\
\hline Lower extremities & & & & & 0,006 \\
$\quad$ - Control group & 10 & 0 & 1 & $0,30 \pm 0,483$ & \\
- Experiment group & 10 & 0 & 2 & $1,10 \pm 0,568$ & \\
\hline
\end{tabular}

Based on the research results of Table 2, the upper limb in the control group get that difference in muscle strength highest score is 1 and the lowest is 0 , the average muscle strength was $0.20 \pm 0.442$. While the value of muscle strength in the experimental group, in get that difference in muscle strength highest scores is 2 and the lowest is 0 , the average muscle strength was $1.00 \pm 0.471$. And the lower limb control group, the difference in muscle strength highest score is 1 and the lowest is 0 , the average muscle strength was $0.30 \pm 0.483$. While the value of muscle strength in the experimental group, in get that difference in muscle strength scores highest is 2 and the lowest is 0 , with an average of muscle strength was $1.10 \pm 0.568$. Mann Whitney test results for both groups obtained p-value of the upper extremities was $0.002(\mathrm{p}<0.05)$ and at the lower extremities was $0.006(\mathrm{p}<0.05)$, which means that there are differences in changes in muscle strength improvement of upper and lower extremities significant between the two groups after the given range of motion exercises for seven days as much as 2 times a day.

\section{DISCUSSION}

Respondents in the control group did not experience an increase in muscle strength due to several things like physiotherapy implementation irregular or regular and is influenced by comorbidities. In this study, the majority of the group of respondents aged $>50$ years that there are seven respondents, and comorbidities such as diabetes mellitus and heart disease which are 2 respondents who suffer from diabetes mellitus and a person suffering from heart disease.

According Kozier and Olivery (1995) that quoted by Williams, et al. (2010) that the higher age in stroke patients, the recovery will be longer than the stroke patient younger age because with increasing age, the higher the overall decline in organ function so will give a different effect recovery among young stroke patients with age further.

The age factor is known to have a significant relationship with the improvement of neurological function. Elderly patients are often unable to follow the rehabilitation program, as was done in stroke patients with younger age because of intolerance experienced by them in the exercise activities (Petrina, 2007). 
These results are supported by research conducted by Hayes, et al., (2003) on the influence of gender and age on disability ischemic stroke patients, found that nearly half of elderly stroke patients $(43 \%)$ had moderate to severe neurological deficits, so that patients have dependence in Activity Daily Living (ADL).

In addition to age and comorbidities, gender differences participate in the process of post-stroke recovery. In the control group mostly comprised of female respondents are 6 people $(60 \%)$. Gender is known to have a relationship with post-stroke recovery. This is consistent with research conducted by Oh, Yu, Spirit, and Lee (2009) about gender differences in mortality rates and outcomes of stroke patients in Korea. This study concluded that women stroke has a longer life expectancy than men, but have functional status post stroke worse than men.

The results of study are consistent with research conducted by Maimurahman and Fitria (2012) on the effectiveness ROM of the extremity muscle strength in patients with stroke, the result is that there are significant differences in the degree of muscle strength before and after exercise ROM with p-value was 0,003 with of $z$-value was -3.000 . And as also research conducted by Mawarti and Farid (2012) on the effects of passive ROM exercises to increase muscle strength in stroke patients with hemiparesis can be concluded that there are significant passive ROM exercises 2 times a day for muscle strength in stroke patients with hemiparesis with p-value was 0,000 .

ROM exercises is rehabilitative therapy that aims to improve or maintain muscle strength and flexibility. Provide early range of motion exercises can improve muscle strength because it can stimulate the muscle unit so the more muscle units involved, there will be an increase in muscle strength (Irfan, 2010).

This finding is supported by the theory of brain plasticity is the ability of the brain to reorganize in the form of a new interconnection on the nerves. Plasticity is a trait that shows the brain's capacity to change and adapt to functional requirements, this mechanism includes a chemical change, acceptance nerves, changes in the structure and organization of the brain nerve neurons (Irfan, 2010).

ROM exercises is useful in maintaining the flexibility of the muscles joints with muscle movement either actively or passively. ROM exercises can be given to all the joints of the body or only part of the body joints. Active movement generated by the internal strength and while passive motion generated by an external force. When the muscles can't contract or muscle relaxation voluntarily to perform the movement, in other words passive motion is the motion moved by others (Soeparman, 2004; Black \& Hawks, 2009).

In the experimental group, obtained largely increased muscle strength after a given range of motion exercises as many as 8 people, there are 3 respondents experienced an increase in muscle strength with the difference in value of muscle strength with a value of 2. In this case the researchers assume that factors affecting muscle strength not only range of motion exercises, but many factors that support the improvement of limb 
muscle strength is the paralysis, age, therapy is given during therapy treatments such as $\mathrm{O}_{2}$, as well as the administration of hypertonic fluids.

In the experimental group the majority of respondents suffered paralysis on the right side as many as seven people. The paralysis is one of the risk factors for the increase in muscle strength in the experimental group. This is in line with the results of research conducted by Whitall, Waller, Silver and Macko (2000) which concluded that there is a difference between the basic motor functions clients who have lesions in the dominant and non-dominant hemisphere. From the results of his research found that there is a clear advantage for the client motor function during exercise in clients who have lesions in the dominant hemisphere (parese the non-dominant hand) compared with the nondominant hemisphere (parese the dominant hand). Therefore, the approach while doing exercises on clients with specific needs hemiparese by side hemiparese experienced by clients.

Parese (weakness) in the non-dominant hand is not so difficult for the patient, because the patient's daily activities can still be carried out by the dominant hand healthy. Therefore, in the end client care less experienced hands parese because all activities can be carried out by the dominant hand healthy. This of course will worsen parese conditions experienced by the non-dominant hand. However, the opposite occurs if the experience parese is dominant hand. By the time the patient has parese dominant hand, then the client will attempt to train the hand parese to return can do skills that previously could be done by the hand. Therefore there is a difference in motivation between clients who have parese the dominant and non-dominant hand. This can affect the process of rehabilitation in stroke patients (Whitall, Waller, Silver \& Macko, 2000).

In addition to ROM exercises and side paralysis, age factor was affecting the increase in muscle strength associated with the rehabilitation process. Stroke patient rehabilitation process is a process of motor learning which is a set of processes that affect the motor exercises internal state of the central nervous system. ROM exercises conducted involving long-term memory of motor skills and relearn so much easier for patients to have the motor skills that have been in the first study (Mudie and Matyas, 2000). Old age is known to have long-term memory skills are less well than younger age, so this is an impact on recovery ability.

This is in line with research conducted by Bagg, Pombo and Hopman (2002), that age greatly affect the functional ability of stroke patients, which is associated with the ability of young patients better in exercise rehabilitation and recovery process of brain tissue at a young age faster compared with elderly.

Research Bagg, Pombo and Hopman (2002) are also in line with research conducted by Ones, Yalcinkaya, Toklu and Caglar (2009) who found that age contributes to the motor skills of stroke patients. In the research described that age had a significant effect on motor skills of stroke patients. This is because the ability of young patients in the exercise better when compared with older patients. 
$\mathrm{O}_{2}$ therapy in the management of acute stroke patients in maintaining cerebral oxygenation and hypertonic fluids such as mannitol and $0.9 \%$ normal saline which can reduce edema, thus preventing an increase in intracranial pressure thus reducing the impact of stroke by protecting the ischemic area so as not to undergo infarction (Mansjoer, 2000) .

This research was supported by research conducted by Sikawin, Mulyadi and Palandeng, (2013) on the effect ROM exercise on muscle strength in patients with stroke, research shows that there are significant ROM exercises on muscle strength in stroke patients after the ROM for one week with p- value was 0.003 .

ROM exercises beneficial in maintaining the flexibility of the muscles joints with muscle movement either actively or passively. Where is the patient who is actively moving the joints of the extremities without outside assistance or others such as nurses, whereas for passive movements that patients assisted by a nurse to move the limbs. Range of motion exercises can be given to all the joints of the body or only part of the body joints. Active movement generated by the internal strength and while passive motion generated by an external force. When the muscles cannot contract or muscle relaxation voluntarily to perform the movement, in other words passive motion is the motion moved by others (Soeparman, 2004; Black \& Hawks (2009).

Contraction mechanism can increase voluntary muscle in the extremities. Passive ROM exercises can lead to stimuli that increase the activity of the chemical, neuromuscular and muscular, the activity will continue to increase in the presence of stimuli from the outside and from the inside. The voluntary muscles of the extremities contain actin and myosin figment which has chemical properties and interaction between one and the other. Interaction process is activated by calcium ions, and adeno triphospot (ATP), further broken down into adenosine diphosphate (ADP) to provide energy for muscle contraction extremities. Through neuromuscular stimulation will increase the stimulation of the nerve fibers limb muscles which stimulate the parasympathetic nervous especially for asetilcholin production, resulting in contraction. The mechanism through muskuluis primarily voluntary muscles in the extremities will increase the metabolism of mitochondria to produce ATP which is utilized by the voluntary muscles extremities as energy for contraction and increase voluntary muscle tone in the extremities (Guyton, 2007).

Based on the description above that ROM exercises can improve the strength of upper and lower extremities in stroke patients in neurology unit Dr. M. Djamil Padang hospital. For seven days in the acute phase has given changes in muscle strength upper and lower extremities in stroke patients. This course will be both increased muscle when performed more than seven days for example, two weeks or four weeks since the golden period in the recovery of stroke patients are in the first month to six months (Pinzon, 2012).

The parts of the body can be passive and active ROM exercises are the neck, fingers, arms, elbows, shoulders, ankles, feet and ankles will reduce the complications of stroke 
so that the healing process after a stroke would be faster so that patients feel more comfortable.

\section{CONCLUSION}

There is a significant difference in mean muscle strength between the control group and an experimental group with p-value at the upper extremities and the lower extremities are 0.002 and 0.006 , which means the ROM exercises can improve muscle strength extremities in stroke patients. Researchers suggest that: 1) The ROM exercises can be used as a nursing intervention in the provision of nursing care; 2) The ROM exercises should be done early and programmed in each institution nursing services either by nurses or in cooperation with the family after the first families were taught about the range of motion exercises; 3) Created a permanent procedure (SOP) and ROM exercises schedule clearly as the frequency of 2 times a day every morning and afternoon; 4) Provide training and guidance to nurses on the implementation of the ROM exercises either passively or actively in stroke patients; 5) The need for further research on the effect of ROM exercises for muscle strength in patients with stroke homogeneity of the sample so as to enhance the study.

\section{REFERENCES}

Bagg, S., Pombo, A. P. \& Hopman, W. (2002). Effect of age functional out come after stroke rehabilitation. American Stroke Association, 33, 179-185.

Batticaca, F.B. (2012). Asuhan keperawatan pada klien dengan sistem persarafan [Nursing care to clients with the nervous system]. Jakarta: Salemba Medika.

Black,J.M., \& Hawks,J.H., (2009). Medical surgical nursing clinical management for positive outcomes, $8^{\text {th }}$ Edition. St Louis Missouri : Elsevier Saunders

Dahlan, SM. (2012). Statistik untuk kedokteran dan kesehatan: Deskriptif, bivariat dan multivariat, dilengkapi aplikasi dengan menggunakan SPSS. Ed. V[Statistics for medicine and health: Descriptive, bivariate and multivariate, equipped with an application using SPSS. $5^{\text {th }}$ Edition]. Jakarta: Salemba Medika.

Feigin, V. (2007). Stroke. Jakarta: Bhuana Ilmu Populer.

Guyton, Arthur C. (2007). Buku Ajar Fisiologi Kedokteran [Textbook of Medical Physiology]. Jakarta: EGC.

Hayes, M.K., Beiser, A., Kase, C.S., Scaramucci, A., D’Agostino,R.B. \& Wolf, P.A. (2003). The Framingham Study: The influence of gender and age on disability following ischemic stroke, 12(3), 119-126.

Irfan, M. (2010). Fisioterapi bagi insan stroke [Physiotherapy for human stroke]. Yogyakarta: Graha Ilmu.

Maimurahman, H. \& Fitria, C. N. (2012). Keefektifan range of motion (ROM) terhadap kekuatan ekstremitas pada pasien stroke [The effectiveness of range of motion (ROM) on the strength of the extremities in stroke patients]. Tidak Dipublikasi [not Published].

Mansjoer, A, et al. (2000). Kapita selekta kedokteran [Capita medical selekta]. Jakarta: Media Aesculapius.

Mawarti, H. \& Farid. (2012). Pengaruh latihan rom (range of motion) pasif terhadap peningkatan kekuatan otot pada pasien stroke dengan hemiparase [Rom exercise 
influence (range of motion) passive to increase muscle strength in stroke patients with hemiparase]. Journal Eduhealth, 2 (2). diakses pada tanggal 12 September 2014 dari http://www.journal.unipdu.ac.id_accessed on September 12, 2014 from http://www.journal.unipdu.ac.id]

Mudie, M. H., \& Matyas, T. A. (2000). Can simultaneous bilateral movement involve the undamaged hemisphere in reconstruction of neural networks damaged by stroke?, Disability \& Rehabilitation, 22(1/2), 23-37.

National Stroke Association. (2009). What is stroke?. Diakses tanggal 12 September 2014 pada http://www.stroke.org [Accessed September 12, 2014 at http://www.stroke.org

Notoadmodjo, S. (2010). Metodelogi penelitian kesehatan [Health research methodology]. Ed. Rev. [Revision Edition]. Jakarta: Rineka Cipta.

Notoadmodjo, S. (2012). Metodelogi penelitian kesehatan [Health research methodology]. Ed. Rev.[Revision Edition]. Jakarta: Rineka Cipta.

Oh, M., Yu, K., Roh, J., \& Lee, B. (2009). Gender differences in the mortality and outcome of stroke patients in korea. Cerebrovascular Diseases, 28(5), 427-434

Ones, K., Yalçinkaya, E. Y., Toklu, B. C., \& Caglar, N. (2009). Effects of age, gender, and cognitive, functional and motor status on functional outcomes of stroke rehabilitation. NeuroRehabilitation, 25(4), 241-249.

Paternostro-Sluga, T. et al. (2008). Reliability and Validity of The Medical Research Council (MRC) Scale and A Modified Scale For Testing Muscle Strenght In Patients With Radial Palsy. 40, 665-671

Perry, A. G. \& Potter, P. A. (2006). Buku ajar fundamental keperawatan: konsep, proses dan praktik [Textbook fundamentals of nursing: concepts, processes and practices]. Ed. 4 [4 ${ }^{\text {th }}$ Edition]. Jakarta: EGC.

Perry, A. G. \& Potter, PA. (2008). Buku ajar keperawatan medikal-bedah brunner\&suddarth [Textbooks medical-surgical nursing brunner \& suddarth]. Ed. 8 [8 $8^{\text {th }}$ Edition]. Jakarta: EGC.

Perry, AG. \& Potter, P. A. (2011). Basic nursing. Ed.7. Canada: Mosby Elsavier.

Petrina, B. (2007). Motor recovery in stroke. diakses pada tanggal 15 September 2014 http:emedicine.medscape.com. [accessed on September 15, 2014 at http:emedicine.medscape.com]

Pinzon (2012). Buku Saku Stroke [Handbook Stroke]. Jakarta: EGC.

Saputra, L. (2013). Keterampilan dasar untuk perawat dan bidan [Basic skills for nurses and midwives].Tanggerang Selatan: Binarupa Aksara Publisher.

Sikawin, Mulyadi dan Palandeng, C.A, Mulyadi \& Palandeng, H. (2013). Pengaruh latihan range of motion terhadap kekuatan otot pada pasien stroke di irna $f$ neurologi BLU RSUP Prof. Dr. R. D. Kandau Manado [Effect of range of motion exercises on the muscle strength in patients with stroke in IRNA F BLU neurology department of Prof. Dr. RD Kandau Manado] diakses pada tanggal 12 September 2014 dari http://ejournal.unsrat.ac.id_[accessed on September 12, 2014 from http://ejournal.unsrat.ac.id]

Soeparman. (2004). Panduan senam stroke [Guide gymnastics stroke]. Jakarta: Puspa swara.

Sunyoto, D \& Setiawan, A. (2013). Buku ajar statistik kesehatan parametrik, non parametrik, validitas dan reliabilitas [Health statistics textbook parametric, non-parametric, validity and reliability]. Yogyakarta: Nuha Medika. 
Whitall, J., Waller, S.M., Silver, K.H.C., \& Macko, R.F. (2000). Repetitive bilateral arm training with rhythmic auditory cueing improves motor function in cronic hemiparetic stroke. Stroke, 31, 2390-1395

Williams, Jane, et al. (2010). Acute stroke nursing. United Kingdom: Wiley-Blackwell. 